\title{
Effect of Alumina (Al2O3) Particles on The Mechanical Properties of Magnesium $(\mathrm{Mg})$
}

\author{
Hayder Muneam Abed Zaid ${ }^{1 *}$, Abdul Rahman N. Abed ${ }^{2}$, Hala Salman Hasan ${ }^{3}$
}

\section{Authors affiliations: \\ 1*) Mechanical Engineering \\ Department, Al-Nahrain \\ University, Baghdad-Iraq. \\ hayder.munem@gmail.com}

2) Mechanical Engineering

Department, Al-Nahrain

University, Baghdad-Iraq.

abd.ulrahman2011@yahoo.com

3) Mechanical Engineering

Department, Al-Nahrain

University, Baghdad-Iraq.

halasalman2006@yahoo.com

\section{Paper History:}

Received: $12^{\text {th }}$ May 2019

Revised: 26 ${ }^{\text {th }}$ May 2019

Accepted: 19th June 2019

\begin{abstract}
In the present study, magnesium-based composites reinforced with different volume fractions $(3,5,10$, and 15$)$ vol. $\%$ of micro sized $\mathrm{Al}_{2} \mathrm{O}_{3}$ particulates were fabricated by powder metallurgy technique which involves mixed, compacted and sintered. Powders were mixed by ball milling (without balls) for 6 hours at rotation speed $60 \mathrm{rpm}$. Then powder was compacted at $550 \mathrm{MPa}$ and sintered at $530^{\circ} \mathrm{C}$ for 2 hours. Microstructures of sintered composites have been investigated by scanning electron microscopy (SEM), energy dispersive $\mathrm{X}$-ray spectroscopy (EDX) and X-ray diffraction (XRD) energy dispersive. SEM image of sinter samples exhibit good bonding between the magnesium matrix and the alumina. The microhardness and wear resistance of micro composites has been improved significantly compared to that of pure magnesium. Highest value of microhardness is $97 \mathrm{HV}$ at the volume fraction of $10 \mathrm{vol} . \% \mathrm{Al}_{2} \mathrm{O}_{3}$.
\end{abstract}

Keywords: Mechanical Properties, Magnesium, Powder Metallurgy.

$$
\begin{aligned}
& \text { تأثير جزيئات الألومينا }
\end{aligned}
$$

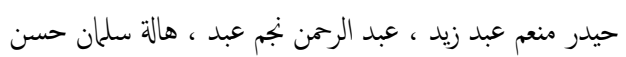

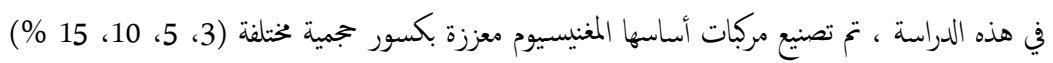

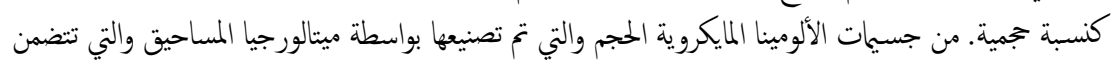

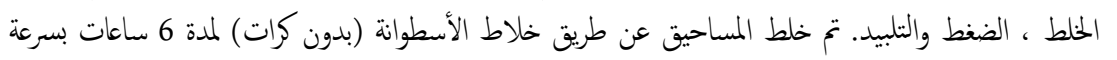

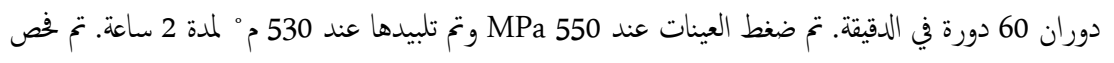
الجمهرية عن طريق مسح الجمهري الإلكتروني (SEM) ، تحليل العناصر المركبة للمركب باستخدام التحليل الطيفي

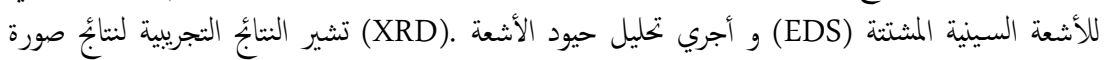

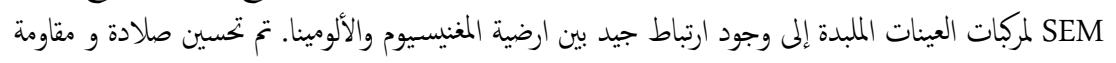
البلى للمركبات بشكل ملحوظ عند مقارنةً بالمغنيسيوم النتي. أفضل القيم لتحسين

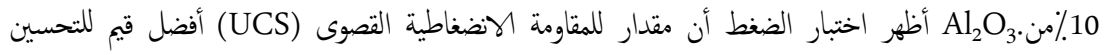

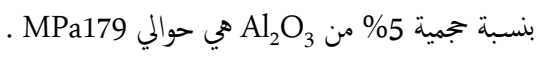

consumer electronics, sports and medical equipment in the future [3]. In recent years, $\mathrm{Mg}$ has also became increasingly appealing for medical applications because of its biocompatibility, biodegradability and similar density of tensile strength, elastic modulus and of human cortical bone[4].

A proper choice of reinforcement is a necessary factor to improve the properties of the matrix material. The selection of reinforcement is done based on the shape and size of the particles, processing method, manufacturing cost and required properties of the composite [5]. If the 
composite is to be used in a structural application, then the strength, modulus, and density are the primary considerable factors. Uniform distribution of reinforcements is also another important factor to improve the properties.

For $\mathrm{Mg}$ matrix composites, the reinforcement can be either ceramic, which is mostly used in metallic. Among these reinforcements, $\mathrm{Al}_{2} \mathrm{O}_{3}$ and $\mathrm{SiC}$ are well known. Even though the improvements of mechanical properties are inferior compared to the fiber reinforcements, they are considered to be advantageous in terms of processing, cost and some other properties like in compressive strength. Particulate reinforcement provides improvement in properties including improved erosion resistance and wear, better damping properties, higher stiffness, and lower thermal expansion coefficient compared to the unreinforced metals and alloys [6][7].

\section{Experimental Procedures}

\subsection{Samples preparation}

In this study, the matrix material is magnesium (Mg) powder with $105 \mu \mathrm{m}$ size and the purity percentage was $99 \%$. The density of magnesium powder was $1.738 \mathrm{~g} / \mathrm{cm}^{3}$ and micro-sized of alumina (Alpha $\mathrm{Al}_{2} \mathrm{O}_{3}$ ) particle with $30 \mu \mathrm{m}$, purity $99.1 \%$ and density $3.97 \mathrm{~g} / \mathrm{cm}^{3}$ were used as reinforcement phase.

The powder metallurgy method was used to prepared both magnesium and micro composites $\left(\mathrm{Mg} / \mathrm{Al}_{2} \mathrm{O}_{3}\right)$ with difference containing 3, 5, 10, and 15 vol.\% fractions of micro alumina respectively. The roller mixer (without balls) for mixing these powders together in order to get a good dispersion, In which the mixture filled a volume of $50 \%$ from the size of the container. 1 vol.\% of stearic acid was added as a process control agent to prevent oxidation of materials, cold welding of particles, reduces the possibility of $\mathrm{Al}_{2} \mathrm{O}_{3}$ agglomeration and separation during mixing [8]. The rotation speed of the cylinders is about $50 \mathrm{rpm}$ for 6 hours [9]. Various homogenized powder mixtures of $\mathrm{Mg}$ and micro alumina were then compacted. Uniaxial cold compaction process was implemented on the mixed material powders by stainless steel die to produce a sample with $12 \mathrm{~mm}$ dimension and length $9.6 \mathrm{~mm}$. In order to find the appropriate pressure to be applied in pressing process, the mixture of $\mathrm{Mg}-10$ vol. $\%$ micro alumina compacted with four different pressing process and they are (400, 500, 550 and 600) $\mathrm{MPa}$. the compacted pressure which gives high green density will be chosen, without surface crack. Form the obtained results the pressure of (550 $\mathrm{MPa}$ ) was appropriate for compaction process of powder and it was determined according to measured density and to avoid the negative effect of over-pressure on samples and mould. Sampling density is determined according to ASTM C20 standard [10]. The compacted sample was then sintered for sintering process electrical tube furnace under vacuum pressure $3 \times 10^{-6}$ bar (non- oxidizing atmosphere) starts from room temperature with average heating rate of $10^{\circ} \mathrm{C} / \mathrm{min}$, maintained until it reaches the sintering temperature, holding time set to be 2 hours' time long, after switching off the furnace, then the samples are cooled inside the furnace gradually and slowly. Identifying the sintering temperature of the specimens based on a higher density. After sintering for four specimens with the same both volume fraction and pressing at $550 \mathrm{MPa}$ under different temperatures (400, 470, 530, and 600$)^{\circ} \mathrm{C}$, below the magnesium melting point $(649)^{\circ} \mathrm{C}$, when the sample is highly dense, its sintering temperature will be chosen. The sintering temperature was chosen at $530^{\circ} \mathrm{C}$ for magnesium composites. The density variation against sintered temperatures and more details are shown in Figure 2.

\subsection{Density and Porosity Measurements}

The density was determined by using Archimedes technique (ASTM C20-00) of sintered samples, weighing the sample in air first (Wa) then suspended in distilled water and weighted again (Ww). An MonoBloc Instrument electronic balance with an accuracy of $0.001 \mathrm{~g}$ was used for recording the weights. The density of the composite samples was obtained using the following formula [10]:

$$
\rho_{e x}=\frac{W a}{W a-W w} \times \rho_{w}
$$

$\rho_{\mathrm{w}}=$ Density of water

The theoretical densities of the samples was calculated using the rule of mixtures as shown in the following formula [11].

$$
\rho_{\text {th }}=\left[\left(\mathrm{f}_{\text {Rei }} \times \rho_{\text {Rei }}\right)+\left(f_{\mathrm{Mg}} \times \rho_{\mathrm{Mg}}\right)\right]
$$

The porosity of the specimen was evaluated via density measurement according to the following formula:

$$
\text { prosity }=\left(1-\frac{\rho_{\text {Ex }}}{\rho_{\text {th }}}\right) * 100 \%
$$

\subsection{Microstructure characterization}

Microstructures of sintered composites have been investigated scanning electron microscopy (SEM), X-ray spectroscopy (EDS) and X-ray diffraction (XRD) energy dispersive.

\subsection{Compression Test}

Compressive properties of $\mathrm{Mg}$ and $\mathrm{Mg} /$ (3, 5, 10, 15) vol. $\% \mu \mathrm{Al}_{2} \mathrm{O}_{3}$ composites samples have a ratio of length to diameter equal to $0.8(12 \mathrm{~mm}$ diameter and $9.6 \mathrm{~mm}$ length) and the subjected strain rate is $5 \times 10^{-3}(\mathrm{~m} / \mathrm{m}$. min) according to ASTM E9-89 a standard. The tests were performed with a device of $25 \mathrm{KN}$ capacity load (CX M500) computerized system [12].

\subsection{Micro hardness Test}

Microhardness measurements were made on the polished $\mathrm{Mg}$ and $\mathrm{Mg} / \mathrm{Al}_{2} \mathrm{O}_{3}$ samples. Vickers microhardness tests were performed by Digital Micro Hardness Tester (TH-714) under a ( $25 \mathrm{gf}$ $=0.245 \mathrm{~N}$ ) test load and dwell time of 15 seconds in accordance with ASTM E3 84-99 [13]. 


\subsection{Wear Test}

The samples were tested using the pin on the disc wear apparatus according to ASTM G99 [14]. With this test, the sample (pin) is mounted into the holder which is loaded by specific weights. The sample (pin) comes in touch with the rotating stainless-steel disk surface.

The weight method was used to calculate the wear rate of the samples. The mass loss $(\Delta \mathrm{M})$ was divided by the sliding distance (S.D) and calculated the wear rate by using the following equation:

$\mathrm{WR}=\Delta \mathrm{M} / \mathrm{S} . \mathrm{D} \quad \Delta \mathrm{M}=\mathrm{M}_{1}-\mathrm{M}_{2} \quad \mathrm{~S} . \mathrm{D}=\omega \mathrm{rt}$

Where: $-\mathrm{WR}=$ Wear rate $(\mathrm{g} / \mathrm{m}), \Delta \mathrm{M}=$ mass losses, $\omega=$ rotating speed of the disc $(\mathrm{rpm}), \mathrm{r}=$ disk radius and $\mathrm{t}=$ slipping time $(\mathrm{min})$.

The dimensions of the samples used in this test are of $12 \mathrm{~mm}$ in diameter and $9.6 \mathrm{~mm}$ in length, loaded with three different weights of $(5,10$, and 15) $\mathrm{N}$, with different sliding distance (100 to 500 ) $\mathrm{m}$. and the rotation speed of the steel disc was $243.7 \mathrm{rpm}$.

\section{Results and Discussion}

\subsection{Measured Density and Porosity}

It could be realized from Figure 1 that there is a decrease in porosity for compaction sample counting 10 vol. $\%$ micro alumina reinforcement from $(28.41 \%$ to $18.13 \%)$ with the increase in the compaction pressure from $400 \mathrm{MPa}$ up to a pressure range close to $550 \mathrm{MPa}$ while after this amount, and with a further increase in compacting force, the decreasing in porosity were (from 18.13\% to $16.82 \%)$. This reduction can be considered as a small improvement in the reduction of porosity compared to the improvement that occurred when the pressure changes from $400 \mathrm{MPa}$ to $500 \mathrm{MPa}$.

It has been noted that high pressure $(600 \mathrm{MPa})$ produces cracks in the green sample and also deformation of the die. Therefore, in order to prevent an excessive load as well as increasing to a limit that might cause a die crack or die deformation and problems of high friction between the compressed powder and the stainless-steel die. A pressure of $550 \mathrm{MPa}$ have been recommended as the best compacting pressure to be used in the powder compacting stage for producing green samples.

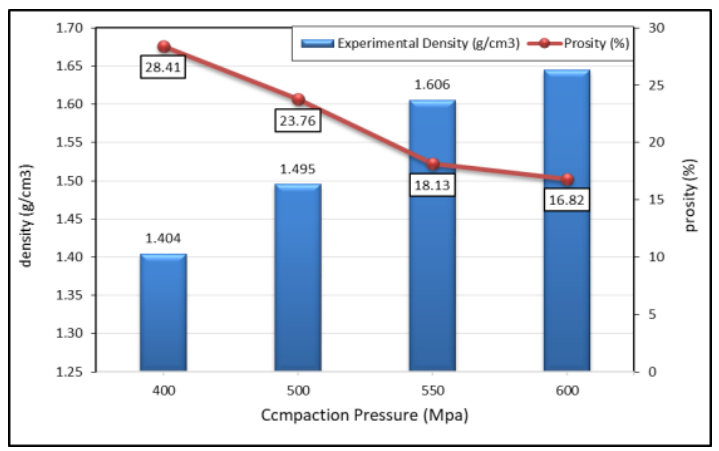

Figure (1): Density and porosity with different cold Compacting pressures for the green sample of 10 vol. $\% \mu \mathrm{Al}_{2} \mathrm{O}_{3} / \mathrm{Mg}$

After the producing of the green sample at best compaction process $550 \mathrm{MPa}$, it will be sintered at a temperature less than the melting temperature of the metal matrix (magnesium).

Figure 2 presents the densities variation of the sintered samples which have been sintered to determine the best density that resulted from various temperatures. by subjecting forth different degrees of temperatures, those were 400, 470, 530 and $600^{\circ} \mathrm{C}$ to determine the best density that resulted from various temperatures. The temperature of $530^{\circ} \mathrm{C}$ have been identified as the best selected one which will provide the highest density after sintering. While with a further increase (to $600^{\circ} \mathrm{C}$ ), the density drops dawn. For if the temperature is lowered to $530^{\circ} \mathrm{C}$, then it will be not enough for the rearrangement of the particles to be able to reduce the porosity. Because high temperature leads to an increase the reaction between the composite components which increase the porosity, low sintering temperature was used $\left(530^{\circ} \mathrm{C}\right)$. Therefore, it has been identified as the best selected temperature which will provide the highest density after sintering.

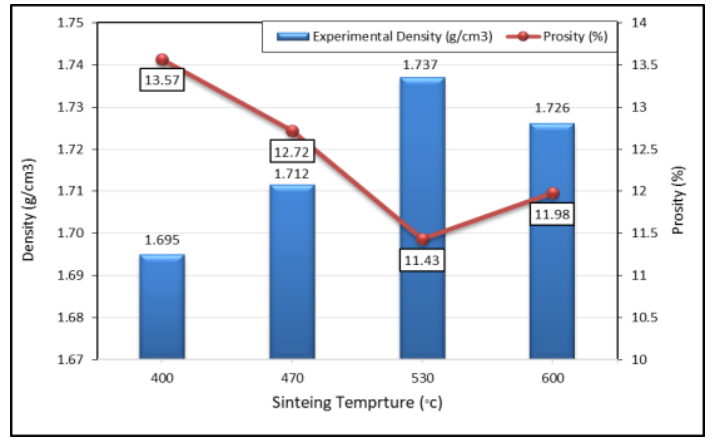

Figure (2): Density variation against sintered temperatures

Composite material of magnesium with micro particle of alumina as shown in Table 1 indicates that the experimental densities of the materials are lower than the theoretically calculated density. It can be seen that the porosity percentage increases with the addition amount of micro alumina particles.

The increase amount reinforcement increases porosity and this is consistent with the preceding studies [15]. It can be concluded that the difference between theoretical and experimental density is regarding to the presence of fine micropores [15] [16]. The first reason of the decreasing of density is related to the high hardness of $\mathrm{Al}_{2} \mathrm{O}_{3}$ reinforcement, it will work as an obstacle against the pressing capacity of samples, and this phenomenon will increase with the increase in the amount of $\mathrm{Al}_{2} \mathrm{O}_{3}$ and lead to an increase in porosity. The second reason is that the tremendous difference in the melting point between alumina and magnesium at the sintering stage; alumina melting point is $\left(2045^{\circ} \mathrm{C}\right)$, which is much higher than the magnesium metal of $\left(649^{\circ} \mathrm{C}\right)$, the mechanism of sintering process will be in the solid state. Therefore, alumina will have low tendency to make bonds with pure magnesium, and then produces a weak network formation between $\mathrm{Mg}$ and $\mathrm{Al}_{2} \mathrm{O}_{3}$ particles .The third reason is that the 
particle size of micro magnesium is $105 \mu \mathrm{m}$, and the size of alumina is $30 \mu \mathrm{m}$, so the empty spaces between magnesium particles are not filled properly with the alumina reinforcement and causes an availability of residual empty spaces, which then leads to an increase in porosity [17].

Table (1): Results of density and Porosity of $\mathrm{Mg}$ micro $\mathrm{Al}_{2} \mathrm{O}_{3}$ composites

\begin{tabular}{|c|c|c|c|}
\hline \multirow{2}{*}{$\begin{array}{c}\text { Material } \\
\text { (vol.\%/Mg) }\end{array}$} & \multicolumn{2}{|c|}{ density $\left(\mathbf{g} / \mathbf{c m}^{3}\right)$} & \multirow{2}{*}{$\begin{array}{c}\text { Porosity } \\
\mathbf{( \% )}\end{array}$} \\
\cline { 2 - 3 } & Theoretical & Experimental & \\
\hline $\mathrm{Mg}$ & 1.738 & 1.691 & 2.73 \\
\hline $3 \mathrm{Al}_{2} \mathrm{O}_{3}$ & 1.805 & 1.715 & 5.01 \\
\hline $5 \mathrm{Al}_{2} \mathrm{O}_{3}$ & 1.850 & 1.720 & 6.99 \\
\hline $10 \mathrm{Al}_{2} \mathrm{O}_{3}$ & 1.961 & 1.737 & 11.43 \\
\hline $15 \mathrm{Al}_{2} \mathrm{O}_{3}$ & 2.073 & 1.724 & 16.82 \\
\hline
\end{tabular}

\subsection{Scanning Electron Microscopy (SEM)} Test

The SEM microstructure images were taken for $\mathrm{Mg}$ and $\mathrm{Mg} / 10$ vol. $\% \mathrm{Al}_{2} \mathrm{O}_{3}$ of sintered samples in order to give a lot of information about the particles' reinforcement distribution, agglomeration and description bonding between $\mathrm{Mg}$ and reinforcement.

Figure 3 illustrates a high degree of the cohesion between magnesium particles and very little of pores are present in the metal. no grain boundaries are to be seen in the magnesium sintered at $530^{\circ} \mathrm{C}$, this may be caused by grain growth then grain coarsening. This will produce grain coalescence and the disappearance of the grain boundaries, but the crystal structure of magnesium will not change to a single crystal. The structure stays polycrystalline.

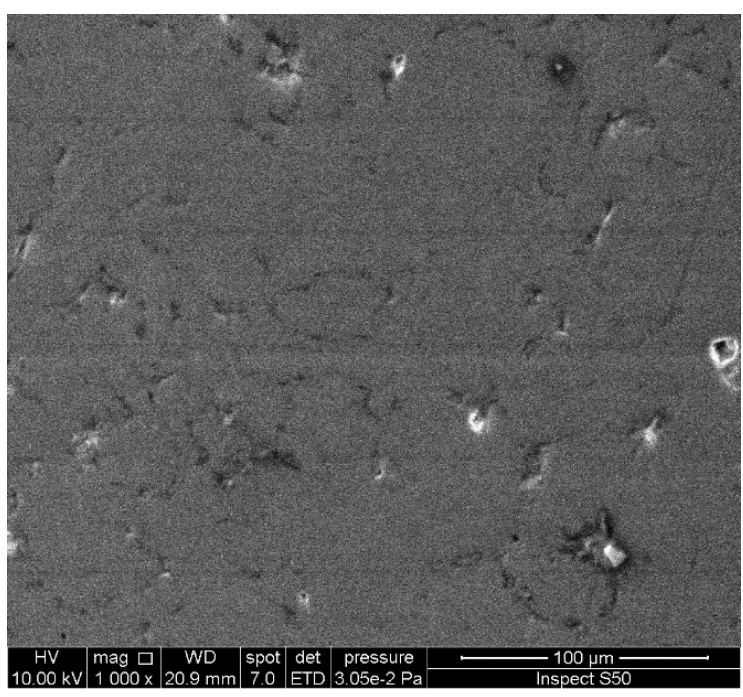

Figure (3): SEM image of pure magnesium

Microstructure examination as shown in Figure 4 at high magnification for micrographs 10 vol. $\%$ micro $\mathrm{Al}_{2} \mathrm{O}_{3}$ in $\mathrm{Mg}$ matrix exhibits good interface between the magnesium matrix and alumina. It can be attributed to the appropriate selection of the best compaction and sintering parameters [9]. In addition to a good compatibility between $\mathrm{Mg}$ and
$\mathrm{Al}_{2} \mathrm{O}_{3}$. Alumina particles are seen individually, separated, and uniformly well distributed with a large bonding area of metal matrix. The reasonably uniform distribution of reinforcement particulates can be attributed to the adoption of suitable mixing parameters [18].

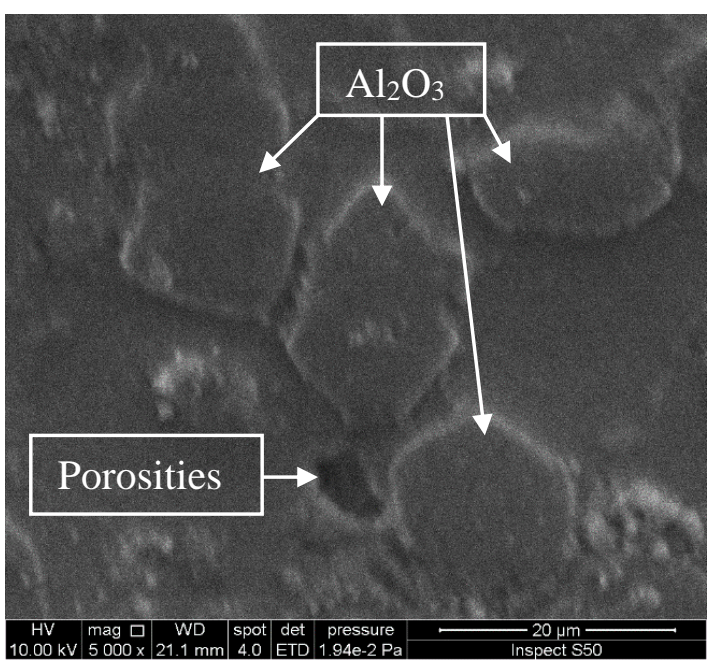

Figure (4): SEM image of $\mathrm{Mg} / 10$ vol. $\% \mathrm{Al}_{2} \mathrm{O}_{3}$ composite

\subsection{Energy Dispersive X-Ray Spectroscopy (EDX)}

The analysis was performed by the composition scanning Energy-Dispersive X-Ray (EDX). in order to analyze the elements and its distribution or chemical characterization of the sample.

Figure $5 \mathrm{EDX}$ of pure magnesium indicates $\mathrm{Mg}$ element only, so there is no creation of oxidations or new phases existed in the sintered pure magnesium sample. Because the process is active under high vacuum.

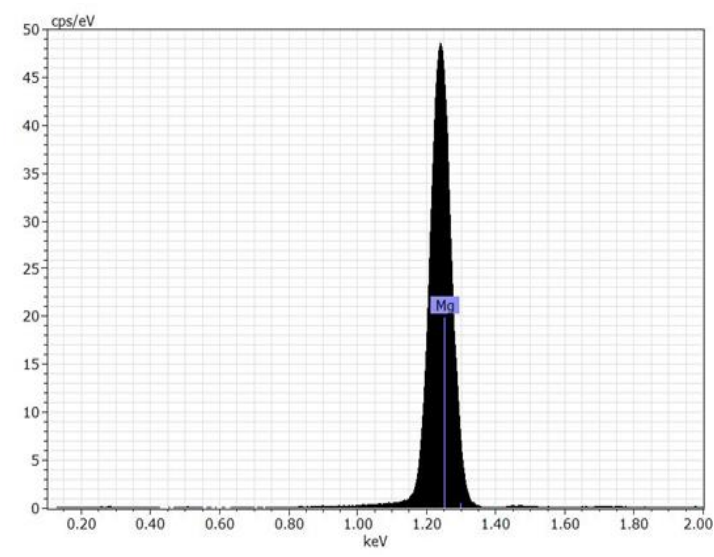

Figure (5): EDX of pure magnesium

EDX analysis of the 10 vol. $\% \mathrm{Al}_{2} \mathrm{O}_{3}$ reinforced $\mathrm{Mg}$ matrix composite. It is clear that the peaks for magnesium, aluminium and oxygen elements as shown in Fig.6.

\subsection{X-Ray Diffraction Analysis (XRD)}

The XRD analysis was used to find out the phases present after sintering. from (Figure 7 and Figure 8 ) are the diffraction patterns obtained for the tested samples. 
Figure 7 shows XRD results revealed that $\mathrm{Mg}$ only phase and did not detected any other phases at all.

As evident from Figure 8, for the formulation containing (10 vol. \% micro $\left.\mathrm{Al}_{2} \mathrm{O}_{3}\right)$ from reinforcement. It can be seen that apart from the two predominant phases of $\mathrm{Mg}$ and $\mathrm{Al}_{2} \mathrm{O}_{3}, \mathrm{MgO}$ and the $\mathrm{Al}_{2} \mathrm{MgO}_{4}$ phase was detected only. The presence of the same phase peaks.

The presence of $\mathrm{MgO}$ in the structure is attributed to high chemical activity between $\mathrm{Mg}$ and $\mathrm{O}$ during the sintering process[19]. Ternary compound $\mathrm{Al}_{2} \mathrm{MgO}_{4}$ can be attributed to be formed by inter-lapping of these three elements on the boundaries between the matrix and $\mathrm{Al}_{2} \mathrm{O}_{3}$ particles, because of $\mathrm{Al}_{2} \mathrm{O}_{3}$ unstable in $\mathrm{Mg}$ reacting to form spinel, $\mathrm{Al}_{2} \mathrm{MgO}_{4}$ reaction of the reinforcement. It can severely degrade the properties of the composite [20]. Energy dispersive X-ray (EDX) analysis confirmed the presence of elements.

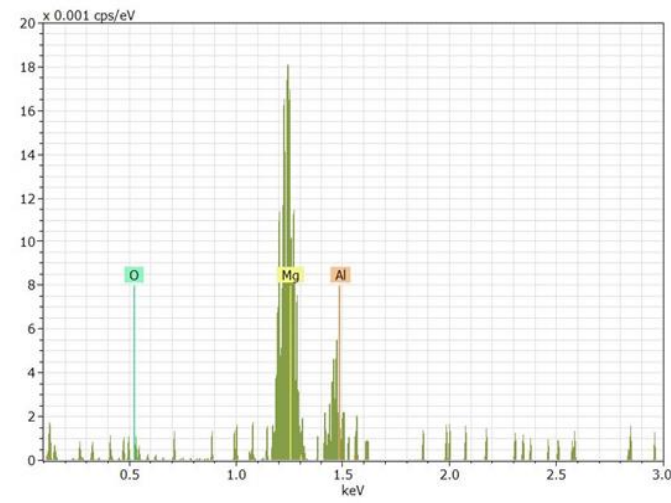

Figure (6): $\mathrm{EDX}$ of $\mathrm{Mg} / 10 \% \mu \mathrm{Al}_{2} \mathrm{O}_{3}$ composite

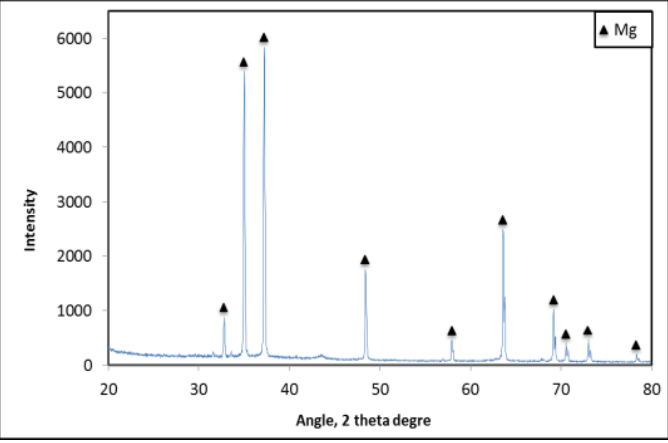

Figure (7): XRD analysis pattern of pure magnesium

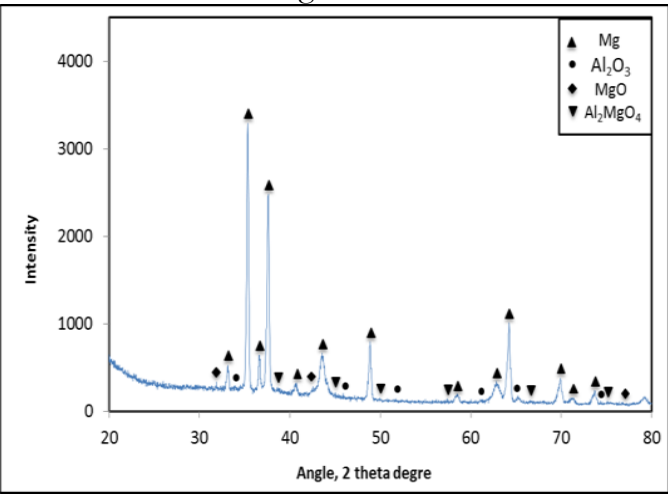

Figure (8): XRD analysis patern of $\mathrm{Mg} / 10$ vol.\% $\mathrm{Al}_{2} \mathrm{O}_{3}$ composite

\subsection{Compression Test}

Figure 9 shows the final compressive strength (UCS) of $\mathrm{Mg}-\mathrm{Al}_{2} \mathrm{O}_{3}$. From the graph, the addition of $\mathrm{Al}_{2} \mathrm{O}_{3}$ particles in the magnesium matrix was found to increase the compressive strength. The best result of UCS in the content of $5 \mathrm{vol} . \% \mathrm{Al}_{2} \mathrm{O}_{3}$. However, an additional increase in micro alumina exceeding the 5 vol. $\%$ up to $15 \mathrm{vol} . \%$, compressive strength will start to minimize. This could be explained by the continuation of increasing the amount of additive after 5 vol.\%. It causes the increased porosity and particle clustering which is responsible for reducing UCS, and ductility despite the beneficial influence of grain refinement [21].

A significant improvement in UCS with increasing percentage of micro $\mathrm{Al}_{2} \mathrm{O}_{3}$ reinforcement can be attributed as follows: 1) the effect of $\mathrm{Al}_{2} \mathrm{O}_{3}$ particles which are employed as a hinder to prevent the movement of dislocations in the magnesium matrix via the dispersion strengthening mechanism [21]. 2) Load bearing effects due to the turnout of reinforcement Load transfer relies on interfacial bonding between the matrix and the reinforcement. Hardness and stronger of $\mathrm{Al}_{2} \mathrm{O}_{3}$ particles which increases load-bearing capacity and effective transfer from soft matrix to solid reinforcement due to good interconnection. Hence the results in improvement of compressive strength [19][22]. 3) Thermal stress and elastic modulus mismatch between the magnesium and $\mathrm{Al}_{2} \mathrm{O}_{3}$ particles could be because of high dislocation density presence of reinforcements increases. The CUS because they cause inhomogeneous deformation and highdensity dislocations. The increase in dislocation density of the composite is related to mismatch of the elastic modulus ( $\mathrm{E}$ of $\mathrm{Mg}$ and $\mathrm{Al}_{2} \mathrm{O}_{3}$ are 44 and $472 \mathrm{GPa}$, respectively [1]) and coefficient of thermal expansion (CTE of $\mathrm{Mg}$ is $27.1 \times 10^{-6} \mathrm{~K}^{-1}$ and $\mathrm{Al}_{2} \mathrm{O}_{3}$ particulates $7.4 \times 10^{-6} \mathrm{~K}^{-1}[23]$ ) between the matrix and the reinforcement material. Therefore, this large difference in CTE and E values lead to the formation of dislocations and rise the strength [19]. And 4) The grain refinement might have an influence on Strength improvement [21].

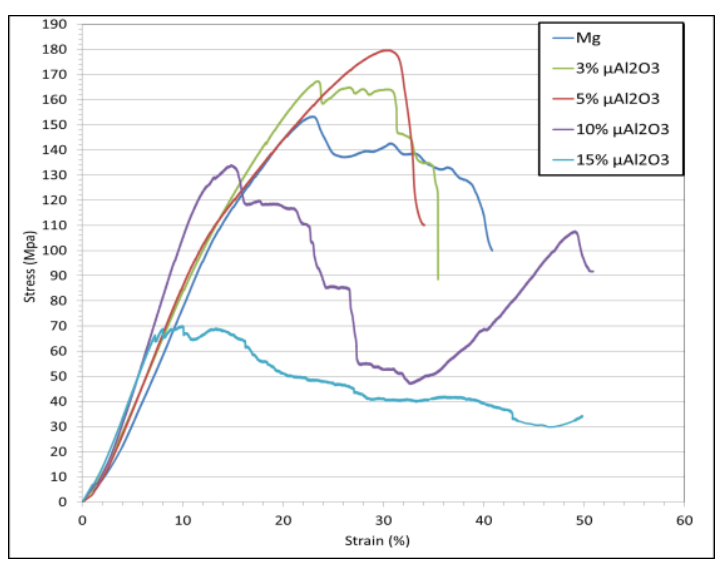

Figure (9): compression strength results of the $\mathrm{Mg} / \mu \mathrm{Al}_{2} \mathrm{O}_{3}$ composites 


\subsection{Micro hardness}

The average micro hardness of $\mathrm{Mg} / \mathrm{Al}_{2} \mathrm{O}_{3}$ composites with $3,5,10$, and $15 \mathrm{Vol} . \%$ of $\mathrm{Al}_{2} \mathrm{O}_{3}$ reinforcement were found to be 43, 56, 97 and 61 $\mathrm{Hv}$, respectively. The micro hardness of pure $\mathrm{Mg}$ was $39 \mathrm{Hv}$. As shown in Figure 10, Microhardness values of micro composites increased markedly compared to unreinforced $\mathrm{Mg}$ materials. Micro hardness data of composites shows an increasing trend of hardness up to $\mathrm{Mg}-10 \%$ micro $\mathrm{Al}_{2} \mathrm{O}_{3}$ composite shows an increment of $149 \%$. However, at $\mathrm{Mg}-15 \% \mu \mathrm{Al}_{2} \mathrm{O}_{3}$ composite has a reduced value of hardness due to the increase of the porosity percentage in the matrix of magnesium.

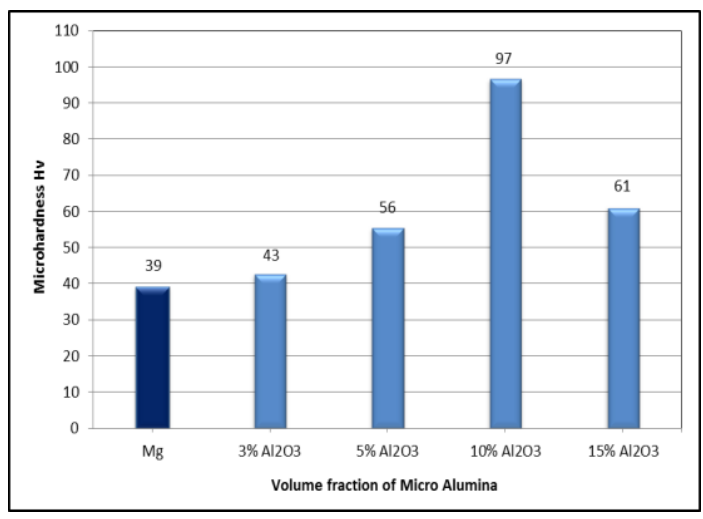

Figure (10): Micro hardness data of $\mathrm{Mg} / \mathrm{Al} 2 \mathrm{O} 3$ microcomposites

The increase in microhardness of micro composites can be attributed primarily to: a) since $\mathrm{Al}_{2} \mathrm{O}_{3}$ particulate is inherently much harder than mg matrix, this can be portended by the simplified basis of the hardness mixtures (Equation following) [21].

$$
\mathrm{H}_{\mathrm{c}}=\mathrm{V}_{\mathrm{m}} \cdot \mathrm{H}_{\mathrm{m}}+\mathrm{V}_{\mathrm{r}} \cdot \mathrm{H}_{\mathrm{r}}
$$

Where: $\mathrm{H}$ is hardness, $\mathrm{V}$ indicates volume fraction, and the symbols, $\mathrm{c}, \mathrm{m}$, and $\mathrm{r}$ indicate composite, matrix, reinforcement, respectively.

b) the presence of hard $\mathrm{Al}_{2} \mathrm{O}_{3}$ particles which acts as a higher constraint to localized deformation of the matrix during indentation [24].

c) The homogenous distribution of hard $\mathrm{Al}_{2} \mathrm{O}_{3}$ particulates in soft $\mathrm{Mg}$ matrix [19].

\subsection{Wear Test}

Wear rate results are shown in two diagrams for each group and compared with the pure magnesium. The first diagram illustrates the wear rate as a function of three different applied loads $(5$, 10 and $15 \mathrm{~N}$ ) in the produced composites after 300 $\mathrm{m}$ sliding distance. The second diagram illustrates the wear rate $(\mathrm{g} / \mathrm{m})$ as a function of sliding distance (m) in the produced composites under $10 \mathrm{~N}$ applied loads.

Figures $11 \& 12$ show the improvement in wear resistance of micro-composite against the sliding distance and applied loads. It could be seen that in changing of the amount of alumina from 3 vol. $\%$ to 10 vol. $\%$, a good improvement in wear resistance has been achieved. While as the amount of alumina increases from 10 vol. $\%$ to 15 vol. $\%$, wear resistance is not improved in same expected way. The main reason of the decreasing in wear rate with increasing amount of alumina in the produced composites is due to the higher hardness of alumina reinforcement added which causes an increase in the hardness of fabricated composites. According to the hardness rule of mixtures, the composite hardness increases with the increase in the amount of alumina addition and reduction in particle size. The drastic reduction in wear mass rate may be attributed to the enhancement in hardness of the composite reinforced by $\mathrm{Al}_{2} \mathrm{O}_{3}$ particles and greater reduction of direct load contact between the $\mathrm{Mg}$ $\mathrm{Al}_{2} \mathrm{O}_{3}$ composite surface and disc in comparison with pure $\mathrm{Mg}$ due to load bearing component action of hard $\mathrm{Al}_{2} \mathrm{O}_{3}$ particles [25] However, when there is an increase of $15 \mathrm{vol} . \% \mathrm{Al}_{2} \mathrm{O}_{3}$, a decrease in wear rate could occur due to the increasing porosity and decreased hardness.

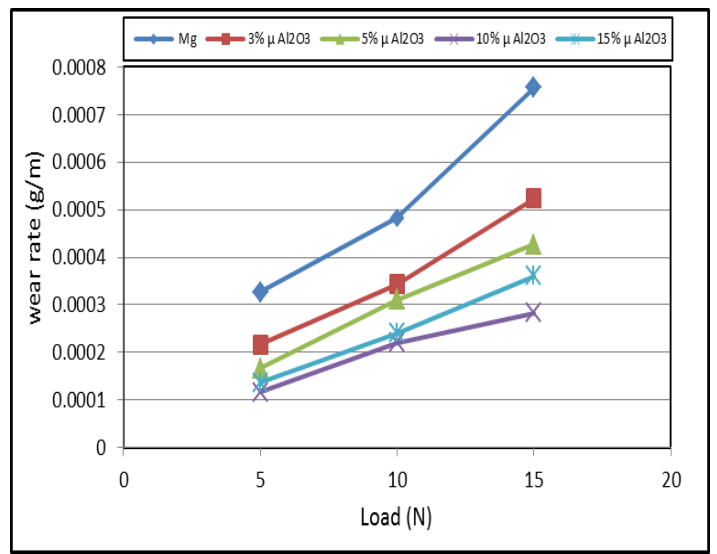

Figure (11): Wear rate of $\mathrm{Mg} / \mathrm{Al}_{2} \mathrm{O}_{3}$ micro composite after $300 \mathrm{~m}$ sliding under 5,10 , and $15 \mathrm{~N}$ applied loads

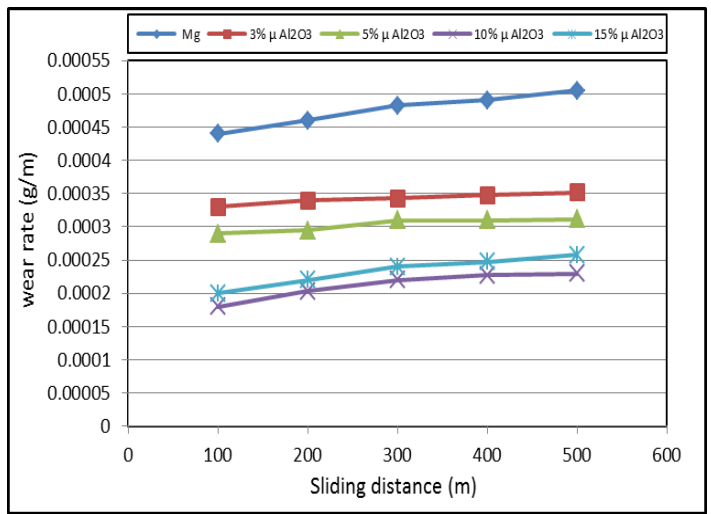

Figure (12): Variation wear rate with sliding distance for $\mathrm{Mg} / \mathrm{Al}_{2} \mathrm{O}_{3}$ micro composite under 10 $\mathrm{N}$ applied load

\section{Conclusions}

The main conclusions of this study are the following:

1. Powder metallurgy (PM) method was successfully used to produce pure $\mathrm{Mg}$ and $\mathrm{Mg}$ micro $\mathrm{Al}_{2} \mathrm{O}_{3}$. When applying a Compaction load at $550 \mathrm{MPa}$ and sintering temperature of $530^{\circ} \mathrm{C}$ for two hours is sufficient enough to fabricate a coherent composite according to the SEM analysis. 
2. The porosity of the composite with $10 \mathrm{vol} . \%$. micro $\mathrm{Al}_{2} \mathrm{O}_{3}$ is reduced from approximately $28.41 \%$ to $16.82 \%$ with compaction with increasing of compaction pressure from 400 $\mathrm{MPa}$ to $600 \mathrm{MPa}$ respectively. It was shown that the best compaction pressure was at $550 \mathrm{MPa}$ for the composite and the porosity in all the composites is higher than that in pure magnesium. The highest porosity values observed is (16.82) with content of 15 vol.\% micro $\mathrm{Al}_{2} \mathrm{O}_{3}$.

3. The composite with 5 vol. $\%$ micro alumina has higher compressive strength which is about (179 $\mathrm{MPa})$.

4. Hardness values of $\mathrm{Al}_{2} \mathrm{O}_{3}$ reinforcement have a tremendous effect on the microhardness in the $\mathrm{Mg}$ matrix composites. The reinforced with 10 vol. $\% \mathrm{Al}_{2} \mathrm{O}_{3}$ particles gave the highest micro hardness reached that improved to $149 \%$ as compared to magnesium.

5. The increasing volume fraction of alumina will increase the wear resistance of the $\mathrm{Mg} / \mathrm{Al}_{2} \mathrm{O}_{3}$ composite the best result of when containing 10 vol. $\mathrm{Al}_{2} \mathrm{O}_{3}$.

\section{References}

[1] M. K. Kulekci, "Magnesium and its alloys applications in automotive industry," no. 2008, pp. 851-865, 2007.

[2] B. L. Mordike and T. Ebert, "Magnesium Properties - applications - potential," vol. 302, pp. 37-45, 2001.

[3] B. Lin and C. Kuo, "Application of an integrated $\mathrm{RE}$ / RP / CAD / CAE / CAM system for magnesium alloy shell of mobile phone," vol. 9, no. 2006, pp. 2818-2830, 2008.

[4] M. Gupta and W. L. E. Wong, "Materials Characterization Magnesium-based nanocomposites: Lightweight materials of the future," Mater. Charact., vol. 105, pp. 30-46, 2015.

[5] C. A. Leon, "Infiltration processing of metal matrix composites using coated ceramic particulates," 2000.

[6] H. Ye, R. T. Alcan, and X. Y. Liu, "Review of recent studies in magnesium," no. January 2004, 2018.

[7] R. P. Minárik, "Effect of composition and microstructure on mechanical and corrosion properties in magnesium alloys with a potential for medical applications," 2014.

[8] T. Z. Wei, S. R. B. Shamsuri, S. Y. Chang, M. W. A. Rashid, and Q. Ahsan, "Effect of sliding velocity on wear behavior of magnesium composite reinforced with SiC and MWCNT," Procedia Eng., vol. 68, pp. 703-709, 2013.

[9] S. F. Hassan and M. Gupta, "Development of high performance magnesium nano-composites using nano- $\mathrm{Al}_{2} \mathrm{O}_{3}$ as reinforcement," Mater. Sci. Eng. $A$, vol. 392, no. 1-2, pp. 163-168, 2005.

[10] S. T. Methods, "Standard Test Methods for Apparent Porosity, Water Absorption, Apparent Specific Gravity, and Bulk Density of Burned Refractory Brick and Shapes by Boiling Water 1," vol. 00, no. Reapproved 2010, pp. 2010-2012, 2012. [11] D. Rajamani and B. Esakki, "Synthesis and
Characterization of Sintered AZ91D Magnesium Matrix Composites Reinforced with Red Mud particles Synthesis and Characterization of Sintered AZ91D Magnesium Matrix Composites Reinforced with Red Mud particles," no. December, 2016.

[12] ASTM-E9-89a, "Standard test methods of compression testing of metallic materials at room temperature," Annu. B. ASTM Stand., vol. 03.01, no. Reapproved, 1996.

[13] ASTM B 933 - 04, "Standard Test Method for Micro indentation Hardness of Powder Metallurgy (P/M) Materials" ASTM International,” 2004.

[14] ASTM G 99 -95a, "Standard Test Method for Wear Testing with a Pin-on-Disk Apparatus," ASTM International, 2000.

[15] H. Y. Wang, Q. C. Jiang, Y. Wang, B. X. Ma, and F. Zhao, "Fabrication of $\mathrm{TiB}_{2}$ participate reinforced magnesium matrix composites by powder metallurgy," Mater. Lett., vol. 58, no. 27-28, pp. 3509-3513, 2004.

[16] H. Y. Wang, Q. C. Jiang, Y. Wang, B. X. Ma, and $\mathrm{F}$. Zhao, "Fabrication of $\mathrm{B}_{4} \mathrm{C}$ particulate reinforced magnesium matrix composite by powder metallurgy," vol. 58, pp. 3509-3513, 2004.

[17] M. Rahimian, N. Parvin, and N. Ehsani, "Investigation of particle size and amount of alumina on microstructure and mechanical properties of $\mathrm{Al}$ matrix composite made by powder metallurgy," vol. 527, pp. 1031-1038, 2010.

[18] S. F. Hassan and M. Gupta, "Effect of nano$\mathrm{ZrO} 2$ particulates reinforcement on microstructure and mechanical behavior of solidification processed elemental Mg," J. Compos. Mater., vol. 41, no. 21, pp. 2533-2543, 2007.

[19] F. Aydin, Y. Sun, H. Ahlatci, and Y. Turen, "Investigation of Microstructure, Mechanical and Wear Behaviour of $\mathrm{B}_{4} \mathrm{C}$ Particulate Reinforced Magnesium Matrix Composites by Powder Metallurgy," Trans. Indian Inst. Met., 2017.

[20] D. J. Lloyd, "Particle reinforced aluminium and magnesium matrix composites," vol. 39, no. 1, 1994.

[21] R. Rahmany-Gorji, A. Alizadeh, and H. Jafari, "Microstructure and mechanical properties of stir cast $\mathrm{ZX} 51 / \mathrm{Al}_{2} \mathrm{O}_{3}$ p magnesium matrix composites," Mater. Sci. Eng. A, vol. 674, pp. 413-418, 2016.

[22] S. F. Hassan and M. Gupta, "Effect of lengh scale of $\mathrm{Al} 2 \mathrm{O} 3$ particulates on microstructural and tensile properties of elemental Mg," J. Alloys Compd., vol. 425, no. 1-2, pp. 22-27, 2006.

[23] S. F. Hassan and M. Gupta, "Effect of type of primary processing on the microstructure, CTE and mechanical properties of magnesium/alumina nanocomposites," Compos. Struct., vol. 72, no. 1, pp. 19-26, 2006.

[24] W. L. E. Wong, S. Karthik, and M. Gupta, "Development of hybrid $\mathrm{Mg} / \mathrm{Al}_{2} \mathrm{O}_{3}$ composites with improved properties using microwave assisted rapid sintering route," vol. 0, pp. 3395-3402, 2005.

[25] H. Li et al., "Fabrication and properties of magnesium matrix composite reinforced by urchinlike carbon nanotube-alumina in situ composite structure," J. Alloys Compd., 2018. 